\section{Centenary of the Royal Dockyard Schools}

At Portsmouth on March 28 the Royal Dockyard School celebrated its centenary when Mr. A. V. Alexander, First Lord of the Admiralty, distributed the prizes. In his speech to the apprentices $\mathrm{Mr}$. Alexander said that "from the dockyard schools have come many leaders in naval construction and engineering and some had been elected Fellows of the Royal Society. In founding the schools and making attendance compulsory the Admiralty anticipated by twenty-seven years the adoption of compulsory education by the State and anticipated day continuation schools by scores of years." The list of eminent naval constructors, shipbuilders and marine engineers who began their scientific training in the dockyards is indeed a long and distinguished one and the country owes a debt to the pioneering work done by the Admiralty in technical education. There had been a School of Naval Architecture at Portsmouth from 1811 until 1832, but that had been closed in a foolish fit of economy by Sir James Graham, the First Lord. It had left its influence, however, and by 1841 another scheme was afoot for training apprentices, This led finally to an Order in Council of February 1, 1843 , for approving the establishment of schools in the dockyards, each of which had had a committee preparing plans. In 1843 Chatham, Portsmouth and Pembroke Schools were opened, and the schools at Sheerness, Devonport, Deptford and Woolwich were opened between 1844 and 1848. A notable event in the history of the schools was the appointment in 1846 of the Rev. Henry (afterwards Canon) Moseley as the inspector of schools, and it was largely due to his experience, criticism and proposals that the schools were placed on a really sound footing. At the present time no fewer than eleven ex-Portsmouth dockyard apprentices are studying at the Royal Naval College, Greenwich, which was opened in 1873 on the closing of the famous Royal School of Naval Architecture and Marine Engineering at South Kensington.

\section{Continuation of Education Interrupted by War Service}

THE Government has announced that steps are being taken, as at the end of the War of 1914-18, to provide suitably qualified men and women with the means to continue, on demobilization, education or training which has been interrupted by war service, with the object of replenishing the supply of those qualified to fill responsible posts in the professions, industry, including agriculture, and commerce. The scheme will apply to all those whose further education has been interfered with by service in the Armed Forces, civil defence bodies, or by undertaking work of national importance. It is intended to cover training in business concerns as well as courses at universities, tecınical colleges and training colleges. It is also proposed to take steps to provide facilities for those who will be retained by Service Departments during the period of resettlement before demobilization is complete. An interdepartmental committee, including representatives of the universities, is being appointed to ensure that training and educational arrangements are related to prospects of employment at home and abroad. An independent committee will advise the Minister of Labour and National Service, acting through the Appointments Branch of the Ministry, on methods of securing co-operation with professional, industrial and business organizations and with education authorities, in order to assist trained men and women to obtain posts after the War. Lord Hankey will be chairman of both these committees. Inquiries regarding these schemes should be addressed to the Secretary, Board of Education, Belgrave Square, London, S.W.1 (by those normally resident in England or Wales), or to the Secretary, Scottish Education Department, St. Andrew's House, Edinburgh, 1 (by those normally resident in Scotland).

\section{Summer School in Biology and Health}

THE re-organized Central Council for Health Education, which enjoys the support of the Ministry of Health and the Board of Education, together with the most important health and educational associations, is arranging a Summer School in Biology and Health to be held at the Chelsea Polytechnic, London, during August 4-14. The first three days will deal with "The Biological Basis of Education", and various sessions will trace the life of a child from conception to adolescence. The lectures will cover heredity, early childhood, stages of physiological and psychological development, and questions of individual and social health. This course should be of value not only to all teachers and educational administrators, but also to youth leaders, play-centre and nurseryschool workers, health visitors and school nurses, and, indeed, all who have to do with children and young people. The succeeding week will deal with "Biology in the School", and is designed specially for teachers of biology and others interested in that subject. While the mornings will be devoted to 'text-book' biology, and the afternoons to experimental demonstrations and visits, the evening lectures will relate biology to its social setting.

The Council has been fortunate in securing the services of several eminent men of science and educationists. Prof. C. W. Valentine, professor of education in the University of Bristol, will speak on "Early Childhood", and Prof. Winifred E. Cullis on "Sex Education". A matter of great topical importance, "The Social Aspects of Nutrition", will be dealt with by Prof. J. R. Marrack, professor of chemical pathology in the London Hospital Medical College, and if his other engagements permit, Prof. Lancelot Hogben, professor of zoology in the University of Birmingham, will speak on "Biology as a Social Science". It is hoped that other authorities well known for their views on biology as an educational discipline will address the school. The lighter side so essential to the success of a Summer. School has not been neglected. Visits will be arranged to the Science Museum, Kow Gardens, and Rothamsted Experimental Station; socials and dances will be held at the Polytechnic, and time will be left free for other individual arrangements. The Summer School fee will be $5 \frac{1}{2}$ guineas for the full ten days, and $2 \frac{1}{2}$ guineas for the first three days only. These figures include not only tuition, but also lunch, tea, and dinner each day. Since many students will prefer to stay with friends in London, the fee is not calculated to include sleeping accommodation and breakfast, but the organizers of the school will be glad to help other students to make such arrangements. The school will be jointly directed by Mr. L.J. F. Brimble, chairman of the Central Council's Educational Advisory Committee, and Dr. F. J. Harlow, principal of Chelsea Polytechnic. The Summer School Secretary is Mr. Cyril Bibby, Education Officer, Central Council for Health Education, Tavistock House, London, W.C.1, to whom enquiries should be directed. 